\title{
High Stability of a Mitochondrial Genetic Marker mtCOII in Polish Colorado Potato Beetle Populations
}

\author{
Arnika Przybylska • Marta Budziszewska • Tomasz Klejdysz • \\ Jan Nawrot • Aleksandra Obrẹpalska-Stẹplowska
}

Published online: 6 June 2014

(C) The Author(s) 2014. This article is published with open access at Springerlink.com

\begin{abstract}
Colorado potato beetle (CPB) (Leptinotarsa decemlineata (Say in Journal of the Academy of Natural Sciences of Philadelphia 3: 298-331, 1824)) (Coleoptera: Chrysomelidae) is one of the most serious potato pests. It has been reported worldwide, from North America to Europe and Asia. In this study we analyzed the genetic diversity of a mitochondrial DNA marker - a second subunit of cytochrome oxidase ( $m t C O I I)$ in Polish CPB populations to assess the possible changes of this gene sequence over time and over the country, influencing the intra-specific variability of CPB. During a three-year survey in Polish potato fields the beetles were collected from 20 evenly spaced locations of varying climatic and geographic conditions, and the nucleotide sequence of this marker was analyzed. Our research revealed that in spite of three years of sampling the mitochondrial haplotype in all individuals was fixed, and no single nucleotide change was found in any individual, indicating a high stability of this maternally inherited marker in L. decemlineata. This finding about the level of biodiversity is of importance for plant protection strategies.
\end{abstract}

Resumen El escarabajo de la papa de Colorado (CPB) (Leptinotarsa decemlineata (Say in Journal of the Academy of Natural Sciences of Philadelphia 3: 298-331, 1824)) (Coleoptera: Chrysomelidae) es una de las plagas más serias en papa. Se ha reportado en todo el mundo, desde Norteamérica a

A. Przybylska $\cdot$ M. Budziszewska $\cdot$ A. Obrępalska-Stęplowska $(\triangle)$ Interdepartmental Laboratory of Molecular Biology, Institute of Plant Protection - National Research Institute, 20 Władysława Wegorka St, 60-318 Poznań, POLAND

e-mail: olaob@o2.pl

T. Klejdysz $\cdot$ J. Nawrot

Department of Entomology, Institute of Plant Protection - National Research Institute, 20 Władysława Węgorka St, 60-318 Poznań, POLAND
Europa y Asia. En este estudio analizamos la diversidad genética de un marcador de ADN mitocondrial - una segunda subunidad de citocromo oxidasa (mtCOII) en poblaciones polacas de CPB para ver los posibles cambios en la secuencia de este gene en el tiempo y en el país, que estuvieran influenciando la variabilidad intraespecífica del CPB. Durante los tres años del estudio en los campos de papa polacos se colectaron los escarabajos de veinte localidades espaciadas uniformemente de condiciones climáticas y geográficas variables, analizando la secuencia de nucleótidos de este marcador. Nuestra investigación reveló que a pesar de los muestreos por tres años, el haplotipo mitocondrial era fijo en todos los individuos, y no se encontró un solo cambio de nucleótido en ningún individuo, indicando una gran estabilidad de este marcador heredado maternalmente en $L$. decemlineata.

Keywords Leptinotarsa decemlineata $\cdot$ Colorado potato beetle $\cdot m t C O I I \cdot$ Potato pest $\cdot$ Population variability

\section{Introduction}

Potato is one of the most important crops grown in Poland, even though the area of cultivation decreased significantly in recent years (Domochowska 2013). The reason for this decrease are the changes in Polish agriculture after entry to the European Union. Colorado potato beetle (CPB) (Leptinotarsa decemlineata (Say 1824) is the best known and the most recognizable beetle of the family Chrysomelidae (Chrysomelidae) occurring in the country. Despite progress in the protection of plants, which has enabled control of CPB populations, this species is still considered to be the most serious pest of potato crops (Mrówczyński 2000). CPB in Poland rarely feeds on other plants, although they are sometimes found on tomato and eggplant (Lipa and Zych 1994). 
CPB is native to North America, where it has developed on wild plants of the family Solanaceae. With the introduction of potato cultivation in these areas, CPB quickly adapted to development on this plant. Although the presence of the CPB in Europe was recorded in the second half of the 19th century, the beginning of the invasion of Europe is considered to be 1922, when huge areas of plantings in France (near Bordeaux) were overwhelmed by this pest. Over the next few decades, this pest spread to most of the countries of Europe. CPB is absent only in a few, located mainly in the north countries of Europe and in Great Britain (Alyokhin et al. 2013). In Poland, the first certain information on the presence of the CPB was in 1946, when they infested 3 hectares of potato fields near Kielce (Węgorek 1949, 1959). Currently, this pest is widely distributed throughout the country. CPB in Poland appears in large populations on average every 7 10 years (Piekarczyk and S. Pruszyński 1984). Mild winters and cooler springs adversely affect the development of the insect, reducing the population buildups of this pest in recent years in Poland. Entomopathogenic fungi have high activity against overwintering larvae in such conditions (Walczak et al. 2013).

The last intensive survey of European populations of $L$. decemlineata was done more than 10 years ago (20012002) (Grapputo et al. 2005). It indicated that in Europe there is only one mitochondrial haplotype present, fixed in all studied populations, which allowed the authors to suggest that a single successful founder event of CPB occurred on the continent. Because mitochondrial cytochrome oxidase subunit genes are being used increasingly for evaluating intra-specific genetic diversity of organisms we decided to focus our studies on one of these mitochondrial genome fragments in CPB. We analyzed populations of $L$. decemlineata over time in 20 locations in Poland, in what is currently and has been traditionally one of the biggest potato-growing areas in Europe. Moreover, knowing that there is a high genetic fixation of the $m t C O I$ gene marker, we extended our analysis to $m t C O I I$. Mitochondrial genes have a number of biological properties making them suitable for evolutionary research, including maternal inheritance and a nearly neutral mode of evolution (Ballard and Rand 2005). They are also supposed to be good markers for biodiversity studies. The $m t C O I$ gene has also been chosen for standardized molecular taxonomy and identification purposes (Ratnasingham and Hebert 2007). The mitochondrial genome is characterized by a relatively high mutation-fixation rate, estimated as up to ten times higher than that of single-copy nuclear DNA (Palmer et al. 2000). Because the level of biodiversity is of importance for plant protection strategies against agriculturally important pests we wanted to analyze the possible genetic variability of the CPB $m t C O I I$ gene. However, in our research conducted for 3 years in potato fields in Poland, insects from populations collected from 20 distinct locations throughout the country, differing in geographic and climatic conditions, indicated a very high stability with no nucleotide change found in any single individual tested.

\section{Materials and Methods}

\section{Colorado Potato Beetle Samples}

Five Colorado potato beetle specimens were collected each year at each of 20 locations in Poland in 2011-2013, totalling 300 specimens. The insects were trapped from 18 June to 8 July in 2011, from 5 July to 23 July in 2012, and from 21 June to 12 July in 2013. Locations where insects were trapped were evenly distributed throughout Poland (Fig. 1). The average distance between trapping locations was $149.5 \mathrm{~km}$, whereas the average distance between trapping sites in any one location was $2.6 \mathrm{~km}$ each year. Captured insects were placed individually in sealed containers in $96 \%$ ethyl alcohol. Each container was labelled with the date and geographical coordinates where the insects were collected (Table 1). The individuals were used in the study as separate samples.

\section{Genomic DNA Extraction}

DNA was extracted from larvae and adult specimens. Each individual was crushed in liquid nitrogen and part of the tissue (ca. $20 \mathrm{mg}$ ) was taken for DNA extraction. Extraction was performed using DNeasy Blood \& Tissue kit reagents (Qiagen), according to the manufacturer's recommended procedure. Final concentration of DNA was between 50 and 200 ng/ $\mu \mathrm{l}$ (measured using Nano Drop (Thermo Scientific)).

\section{Sequences Analyses and Primer Design}

To find the region suitable for design of the primer pair amplifying the $m t C O I I$ sequence, $L$. decemlineata mtDNA sequences from GenBank were used as well as sequences of other selected species from the Chrysomelidae family: Galerucella birmanica, Platyphora ligata, and Platyphora salvigny. Sequences were aligned and analyzed in Bio Edit (Hall 1999), and regions that were similar for all species were chosen to design primers amplifying the longest fragment of $m t C O I I$ : F1chryso 5'-GTTCTAATATGGCAGATTAGTGC3' and R1chryso 5'-CACAAATTTCTGARCATTGWCC-3'. The quality of the primers was assessed by Oligo Analyzer 3.1 (http://eu.idtdna.com/analyzer/applications/oligoanalyzer/).

\section{PCR Reactions}

The PCR primer pair was tested in PCR reactions with genomic DNA extracted from all $L$. decemlineata samples. A control sample that did not include a DNA 
Fig. 1 General locations in Poland where Colorado potato beetles used in the research were caught

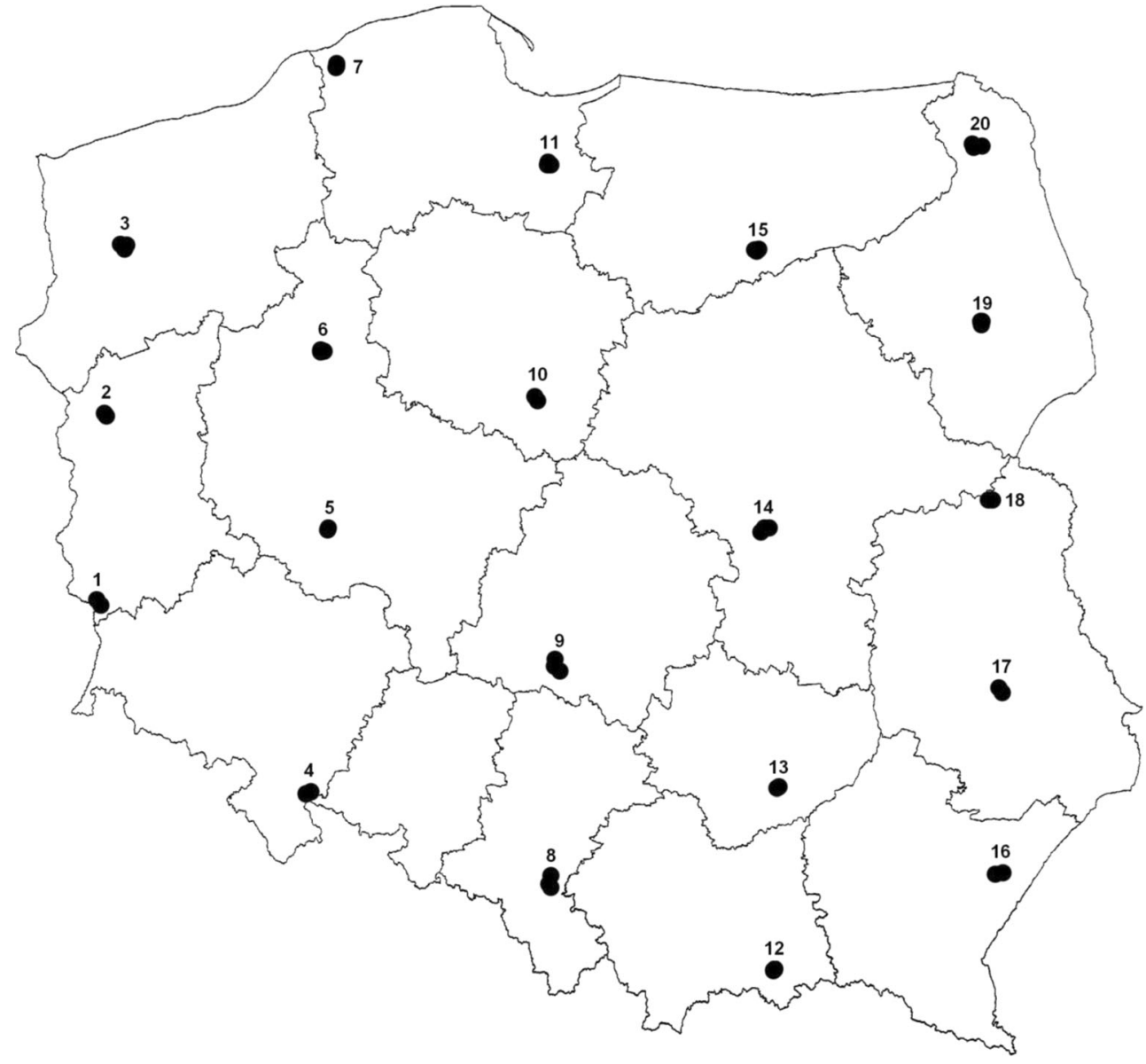

template was also assayed to test for reagent contaminants. All PCR reactions were performed with samples (final volume, $10 \mu \mathrm{l}$ ) containing $1 \mu \mathrm{l}$ of template DNA, $200 \mu \mathrm{M}$ total of the four dNTPs, $1 \mu \mathrm{M}$ of each forward and reverse primer, $1 \times$ AllegroTaq polymerase buffer, 0.2 U AllegroTaq DNA polymerase (Novazym), and sterile distilled water. Amplification conditions were as follows: denaturation for $3 \mathrm{~min}$ at $95{ }^{\circ} \mathrm{C}$ followed by 35 cycles at $95{ }^{\circ} \mathrm{C}$ for $30 \mathrm{~s}, 55^{\circ} \mathrm{C}$ for $30 \mathrm{~s}$, and $72{ }^{\circ} \mathrm{C}$ for $45 \mathrm{~s}$, and a final extension for $5 \mathrm{~min}$ at $72{ }^{\circ} \mathrm{C}$. After PCR reactions, reaction products were analyzed by electrophoresis in $1 \%$ agarose gel. Products visualized with Midori Green (Nippon Genetics Europe, Düren, Germany) were photographed under UV light.

\section{PCR Product Elution and Sequencing}

The PCR product bands were cut out from the gel, and DNA was eluted using Wizard ${ }^{\circledR}$ SV Gel and PCR Clean-Up System (Promega). DNA concentration and quality were determined by using the Nano Drop spectrophotometer (Thermo Scientific). Eluted DNA was used directly as a template for automatic sequencing with primers F1chryso/R1chryso.
Sequences Analysis

The obtained sequences were aligned and analyzed in Bio Edit (Hall 1999) and visualized using GeneDoc software (Nicholas et al. 1997). They were also compared with sequences of $L$. decemlineata representing 20 different haplotypes described by Grapputo and colleagues (2005), deposited in GenBank.

\section{Results and Discussion}

DNA was isolated from all populations collected, and a series of PCR reactions with F1chryso/R1 chryso was conducted. All PCR reactions gave single specific bands of an expected product size (650 bp) (Fig. 2). There was no band observed in the control sample without a template. Obtained products were automatically sequenced, and sequencing results were compared to each other and to the DNA sequences of collected CPB haplotypes available in the Genbank database. The comparative sequence analysis showed no differences between populations or between single specimens regardless of 
Table 1 Locations where Colorado potato beetles were collected

\begin{tabular}{|c|c|c|c|}
\hline \multirow[t]{2}{*}{ No. of positions } & \multicolumn{3}{|c|}{ Geographic coordinates (latitude/longitude hddd ${ }^{\circ} \mathrm{mm}$ 'ss.s") } \\
\hline & 2011 & 2012 & 2013 \\
\hline 1 & $\mathrm{~N} 51^{\circ} 29^{\prime} 05.9^{\prime \prime} ; \mathrm{E} 14^{\circ} 56^{\prime} 46.1^{\prime \prime}$ & $\mathrm{N} 51^{\circ} 28^{\prime} 00.1^{\prime \prime} ; \mathrm{E} 14^{\circ} 57^{\prime} 32.2^{\prime \prime}$ & $\mathrm{N} 51^{\circ} 28^{\prime} 38.2^{\prime \prime} ; \mathrm{E} 14^{\circ} 56^{\prime} 37.7^{\prime \prime}$ \\
\hline 2 & $\mathrm{~N} 52^{\circ} 31^{\prime} 56.2^{\prime \prime} ; \mathrm{E} 14^{\circ} 59^{\prime} 07.1^{\prime \prime}$ & $\mathrm{N} 52^{\circ} 30^{\prime} 14.5^{\prime \prime} ; \mathrm{E} 15^{\circ} 01^{\prime} 08.3^{\prime \prime}$ & $\mathrm{N} 52^{\circ} 32^{\prime} 18.5^{\prime \prime} ; \mathrm{E} 14^{\circ} 58^{\prime} 52.7^{\prime \prime}$ \\
\hline 3 & $\mathrm{~N} 53^{\circ} 29^{\prime} 24.6^{\prime \prime} ; \mathrm{E} 15^{\circ} 01^{\prime} 52.6^{\prime \prime}$ & $\mathrm{N} 53^{\circ} 25^{\prime} 55.4^{\prime \prime} ; \mathrm{E} 15^{\circ} 04^{\prime} 43.8^{\prime \prime}$ & $\mathrm{N} 53^{\circ} 28^{\prime} 30.4^{\prime \prime} ; \mathrm{E} 15^{\circ} 02^{\prime} 19.6^{\prime \prime}$ \\
\hline 4 & $\mathrm{~N} 50^{\circ} 29^{\prime} 23.8^{\prime \prime} ; \mathrm{E} 16^{\circ} 59^{\prime} 27.6^{\prime \prime}$ & $\mathrm{N} 50^{\circ} 28^{\prime} 23.5^{\prime \prime} ; \mathrm{E} 17^{\circ} 00^{\prime} 47.8^{\prime}$ & $\mathrm{N} 50^{\circ} 28^{\prime} 59.8^{\prime \prime} ; \mathrm{E} 17^{\circ} 01^{\prime} 41.5^{\prime \prime}$ \\
\hline 5 & $\mathrm{~N} 51^{\circ} 56^{\prime} 42.0^{\prime \prime} ; \mathrm{E} 17^{\circ} 02^{\prime} 33.4^{\prime \prime}$ & $\mathrm{N} 51^{\circ} 56^{\prime} 47.2^{\prime \prime} ; \mathrm{E} 17^{\circ} 03^{\prime} 00.2^{\prime \prime}$ & $\mathrm{N} 51^{\circ} 56^{\prime} 53.6^{\prime \prime} ; \mathrm{E} 17^{\circ} 03^{\prime} 03.5^{\prime \prime}$ \\
\hline 6 & $\mathrm{~N} 52^{\circ} 55^{\prime} 59.7^{\prime \prime} ; \mathrm{E} 16^{\circ} 54^{\prime} 54.2^{\prime \prime}$ & $\mathrm{N} 52^{\circ} 55^{\prime} 26.0^{\prime \prime} ; \mathrm{E} 16^{\circ} 57^{\prime} 42.1^{\prime \prime}$ & $\mathrm{N} 52^{\circ} 55^{\prime} 10.2^{\prime \prime} ; \mathrm{E} 16^{\circ} 55^{\prime} 34.9^{\prime \prime}$ \\
\hline 7 & N54 30' 57.7"; E16 57' 38.6" & N54 $30^{\prime} 35.8^{\prime \prime} ; \mathrm{E} 16^{\circ} 57^{\prime} 54.1^{\prime \prime}$ & $\mathrm{N} 54^{\circ} 31^{\prime} 02.8^{\prime \prime} ; \mathrm{E} 16^{\circ} 57^{\prime} 56.8^{\prime \prime}$ \\
\hline 8 & N49 59' 11.1"; E190 03' 53.5" & $\mathrm{N} 50^{\circ} 01^{\prime}$ 44.5"; E190 04' 08.6" & $\mathrm{N} 49^{\circ} 59^{\prime} 55.3^{\prime \prime} ; \mathrm{E} 19^{\circ} 04^{\prime} 15.0^{\prime \prime}$ \\
\hline 9 & N51 13' 27.9"; E19 03' 02.3" & 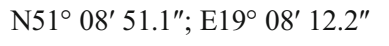 & $\mathrm{N} 51^{\circ} 13^{\prime} 13.3^{\prime \prime} ; \mathrm{E} 19^{\circ} 05^{\prime} 45.8^{\prime \prime}$ \\
\hline 10 & N52 $39^{\prime} 24.1^{\prime \prime} ;$ E18 55' 46.2" & N52 $41^{\prime} 19.7^{\prime \prime} ;$ E18 54' 07.3" & $\mathrm{N} 52^{\circ} 39^{\prime} 21.1^{\prime \prime} ; \mathrm{E} 18^{\circ} 54^{\prime} 53.4^{\prime \prime}$ \\
\hline 11 & N53 59' 05.8"; E18 59' 54.1" & N53 59' 06.7"; E190 00' 02.3" & $\mathrm{N} 53^{\circ} 58^{\prime} 55.4^{\prime \prime} ; \mathrm{E} 19^{\circ} 00^{\prime} 12.9^{\prime \prime}$ \\
\hline 12 & N49 29' 16.2"; E20 59' 03.9" & N49 29' 17.4"; E20 59' 06.3" & $\mathrm{N} 49^{\circ} 29^{\prime} 24.7^{\prime \prime} ; \mathrm{E} 20^{\circ} 59^{\prime} 31.8^{\prime \prime}$ \\
\hline 13 & 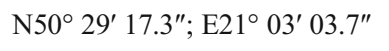 & N5029' 58.5"; E21 ${ }^{\circ} 04^{\prime} 12.7^{\prime \prime}$ & $\mathrm{N} 50^{\circ} 29^{\prime} 49.4^{\prime \prime} ; \mathrm{E} 21^{\circ} 03^{\prime} 25.4^{\prime \prime}$ \\
\hline 14 & N51 $56^{\prime} 40.6^{\prime \prime} ;$ E20 59' 34.5" & N51 $54^{\prime} 52.4^{\prime \prime} ;$ E20 56 $22.5^{\prime \prime}$ & $\mathrm{N} 51^{\circ} 56^{\prime} 28.6^{\prime \prime} ; \mathrm{E} 20^{\circ} 57^{\prime} 43.8^{\prime \prime}$ \\
\hline 15 & $\mathrm{~N} 53^{\circ} 28^{\prime} 04.7^{\prime \prime} ; \mathrm{E} 20^{\circ} 56^{\prime} 37.0^{\prime \prime}$ & $\mathrm{N} 53^{\circ} 29^{\prime} 03.0^{\prime \prime} ; \mathrm{E} 20^{\circ} 58^{\prime} 00.9^{\prime \prime}$ & $\mathrm{N} 53^{\circ} 28^{\prime} 56.6^{\prime \prime} ; \mathrm{E} 20^{\circ} 57^{\prime} 36.5^{\prime \prime}$ \\
\hline 16 & N49 58' 28.3"; E22 $58^{\prime} 39.8^{\prime \prime}$ & N49 57' 51.8"; E22 $53^{\circ} 49.2^{\prime \prime}$ & $\mathrm{N} 49^{\circ} 58^{\prime}$ 09.7"; E22 53'26.0" \\
\hline 17 & $\mathrm{~N} 51^{\circ} 00^{\prime} 06.5^{\prime \prime} ; \mathrm{E} 23^{\circ} 00^{\prime} 26.6^{\prime \prime}$ & N50 58' 06.3"; E23 01' 37.6" & $\mathrm{N} 50^{\circ} 58^{\prime} 06.0^{\prime \prime} ; \mathrm{E} 23^{\circ} 02^{\prime} 46.6^{\prime \prime}$ \\
\hline 18 & $\mathrm{~N} 52^{\circ} 02^{\prime} 01.4^{\prime \prime} ; \mathrm{E} 23^{\circ} 00^{\prime} 13.3^{\prime \prime}$ & $\mathrm{N} 52^{\circ} 02^{\prime} 00.5^{\prime \prime} ; \mathrm{E} 23^{\circ} 00^{\prime} 12.4^{\prime \prime}$ & $\mathrm{N} 52^{\circ} 02^{\prime} 05.8^{\prime \prime} ; \mathrm{E} 23^{\circ} 01^{\prime} 09.1^{\prime \prime}$ \\
\hline 19 & $\mathrm{~N} 53^{\circ} 01^{\prime} 27.5^{\prime \prime} ; \mathrm{E} 23^{\circ} 00^{\prime} 02.6^{\prime \prime}$ & $\mathrm{N} 53^{\circ} 01^{\prime} 26.5^{\prime \prime}$; E23 00' 24.6" & $\mathrm{N} 53^{\circ} 01^{\prime} 17.3^{\prime \prime} ; \mathrm{E} 23^{\circ} 00^{\prime} 00.4^{\prime \prime}$ \\
\hline 20 & N54 01' 10.7"; E22 $59^{\circ} 39.6^{\prime \prime}$ & N53 59' 57.4"; E23 04' 07.7" & N53 59' 58.6"; E23 04' 38.7" \\
\hline
\end{tabular}

the location and collecting year. The identity level between all Polish populations was $100 \%$. The analyzed fragment also showed $100 \%$ identity with populations from haplotypes 1,4 , 13 and 19 in the part of the $m t C O I I$ gene (of about $350 \mathrm{bp}$ ) which was described in the paper by Grapputo et al. (2005). Additionally, in this fragment, Polish populations of L. decemlineata have $98.5-99.7 \%$ identity with CPB populations belonging to other previously identified haplotypes (i.e., 2, 3, 5-12, 14-18, 20) (Grapputo et al. 2005). The sequences from the CPB samples from Poland have been deposited in the GenBank database under accession number KJ156377.

The genetic diversity level might have significant impact on strategies for control of the pest. A reduction in genetic variability might be advantageous in invasiveness, as was shown for Argentinian ants (Tsutsui et al. 2000). Population genetic studies are done with the application of many genetic markers, among them mitochondrial DNA sequences, mostly those encoding $m t C O I$ and $m t C O I I$. These have been successfully applied for the population studies of other insect species (Grapputo et al. 2005, Porretta et al. 2007, Albernaz et al. 2012).

Research on CPB genetic population structure has been done previously, including using the mitochondrial genome. Restriction endonuclease digestion of mitochondrial DNA revealed the presence of 16 haplotypes of this beetle occurring in the USA (Azeredo-Espin et al. 1996). An earlier study done using the same approach on 16 populations from the USA and one from Mexico showed five distinct mtDNA genotypes among the U.S. populations and high divergence between these genotypes and the genotype of the Mexican population. Previous studies also regularly observed size polymorphism

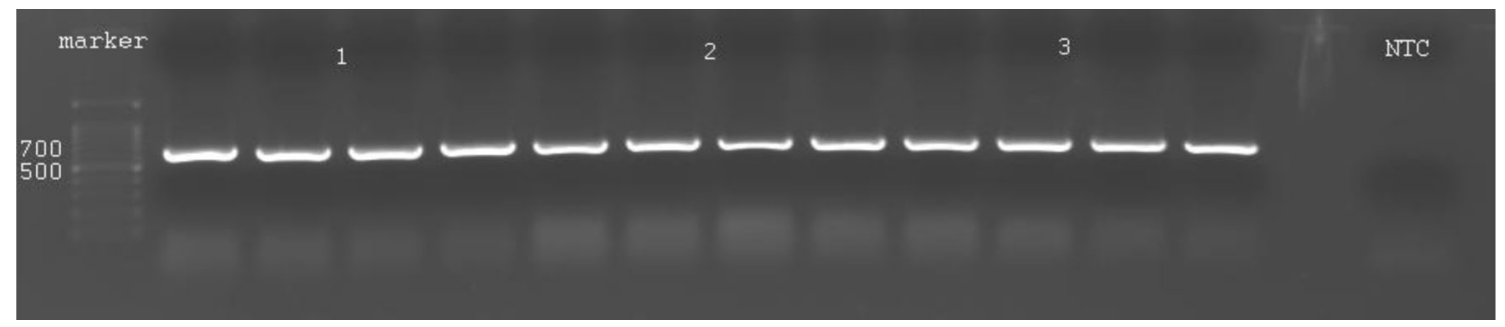

Fig. 2 Examples of $P C R$ products separated by electrophoresis after amplification using F1chryso/R1chryso primer pair. 1, 2, 3 - examples of L. decemlineata populations collected in 2012; NTC - no template control 
of the mitochondrial genome in most populations collected in the USA (Zehnder et al. 1992). Then, North American and European populations of CPB were analyzed on the basis of $m t C O I$ sequence (Grapputo et al. 2005). In this study, 20 haplotypes were described (H1-H20). An analysis of eight European populations from Spain, France, North and South Italy, Estonia, Russia, Finland, and Poland showed that in Europe only haplotype 1 is present (Grapputo et al. 2005). Mitochondrial cytrochrome oxidase subunits ( $m t C O I$ and $m t$ COII) in CPB have a typical gene order found in metazoan mitogenomes: $m t C O I, t R N A^{\text {Leu }}, m t C O I I$. We extended our research on the fragment spanning from $t R N A^{\text {Leu }}$ to $m t C O I I$ in comparison to the aforementioned study. However, our results confirmed lack of inter- and intra-population variability in all analyzed samples collected over the 3 years of the study in Poland, one of the biggest potato-growing countries of Europe, where many different potato varieties are cultivated and bred.

Adults of CPB have a good ability to migrate. In the United States in the late nineteenth century, this species expanded its range an average of $100 \mathrm{~km}$ in one year (Johnson 1967). Long-range migration of CPB can be observed also in Poland. Beetles of this species have been found in places a considerable distance away from the cultivation of potatoes. CPB was, in the past, the most abundant insect washed up on the beaches of the Baltic Sea (Cyrkowski 1980), and seeing this beetle on the beaches still is not unusual (authors' observations). The great ability to disperse is also confirmed by the presence of CPB inside large forest complexes away from any cultivated fields (Byk et al. 2006). Migration is known to play an important role in the stability of interaction between pests and their hosts. It influences gene flow, and its high extent ensures the stability of host-pest interactions. The frequent gene flow in Chinese populations of CPB was also confirmed recently on the basis of analysis of microsatellite markers (Zhang et al. 2013). This is contrary to the study based on AFLP nuclear markers for populations from North America and Europe where low gene flow among populations on both continents was reported (Grapputo et al. 2005). Altogether, our results based on the mtDNA gene and those obtained by Zhang et al. (2013) on microsatellite markers show that both Polish and Chinese populations seem to contain only a fraction of the genetic diversity that occurs on the continent from which this pest originated. The number of CPB invasions in Europe is not known, however, the reduced genetic variability and fixation for a single mitochondrial haplotype suggest a unique (or successful) founder event and, in this regard, our results further support the data presented previously (Grapputo et al. 2005). The low genetic variability might be also be an effect of a relatively recent demographic expansion of $L$. decemlineata populations in Europe.

In conclusion, our study revealed that over all geographic locations, over all 3 years of sampling, the Polish CPB populations remain genetically non-diverse at least in regard to the mitochondrial genome segment $-m t C O I I$. This finding of stability (at least of this maternally-inherited marker) might be of importance for future Integrated Pest Management strategies especially because control of CPB is still a constant challenge.

Acknowledgments The study was supported by the Polish National Science Center grant NN 310 728240. The authors thank Dr. James Throne from the United States Department of Agriculture for the help in editing of the manuscript.

Open Access This article is distributed under the terms of the Creative Commons Attribution License which permits any use, distribution, and reproduction in any medium, provided the original author(s) and the source are credited.

\section{References}

Albernaz, K.C., K.L. Silva-Brandao, P. Fresia, F.L. Consoli, and C. Omoto. 2012. Genetic variability and demographic history of Heliothis virescens (Lepidoptera: Noctuidae) populations from Brazil inferred by mtDNA sequences. Bulletin of Entomological Research 102: 333-343.

Alyokhin, A., M. Udalov, and G. Benkovskaya. 2013. The Corodado potato beetle. In Insect pests of potato: Global perspectives on biology and management, ed. P. Giordanengo, C. Vincent, and A. Alyokhin, 11-29. Oxford: Academic.

Azeredo-Espin, A., R. Schroder, G. Roderick, and W. Sheppard. 1996. Intraspecific mitochondrial DNA variation in the Colorado potato beetle, Leptinotarsa decemlineata (Coleoptera: Chrysomelidae). Biochemical Genetics 34: 253-268.

Ballard, J.W.O., and D.M. Rand. 2005. The population biology of mitochondrial DNA and its phylogenetic implications. Annual Review of Ecology Evolution and Systematics 36: 621-642.

Byk, A., T. Mokrzycki, S. Perliński, and A. Rutkiewicz (eds.). 2006. Saproxylic beetles - in the monitoring of anthropogenic transformations of Białowieża Primeval Forest. Warsaw Agricultural University Press, Warsaw.

Cyrkowski, R.K. 1980. Coleoptera in the coastal marine pollution Stowiński national park. Krakow: XXII Congress of the Polish Entomological Society.

Domochowska, H. 2013. Statistical Yearbook of Agriculture, pp. 443. Statistical Publishing Establishment.

Grapputo, A., S. Boman, L. Lindstrom, A. Lyytinen, and J. Mappes. 2005. The voyage of an invasive species across continents: genetic diversity of North American and European Colorado potato beetle populations. Molecular Ecology 14: 4207-4219.

Hall, T. 1999. Published. Bio Edit: a user-friendly biological sequence alignment editor and analysis program for Windows 95/98/NT, pp. 95-98. In, Nucleic acids symposium series.

Johnson, C. 1967. International dispersal of insects and insect-borne viruses. Netherlands Journal of Plant Pathology 73: 21-43.

Lipa, J.J., and A. Zych. 1994. Quarantine pests of Europe. Warszawa: Inspectorate for Plant Quarantine.

Mrówczyński, M. 2000. Occurrence and control the Colorado potato beetle Leptinotarsa decemlineata in the years 1978-1999. Progress in Plant Protection 40: 292-299.

Nicholas, K. B., H. Nicholas, and D. Deerfield. 1997. Gene Doc: analysis and visualization of genetic variation. Embnew. news 4 . 
Palmer, J.D., K.L. Adams, Y. Cho, C.L. Parkinson, Y.L. Qiu, and K. Song. 2000. Dynamic evolution of plant mitochondrial genomes: mobile genes and introns and highly variable mutation rates. Proceedings of the National Academy of Sciences of the United States of America 97: 6960-6966.

Piekarczyk, K., and S. Pruszyński. 1984. Published. The mass occurrence of the Colorado potato beetle (Leptinotarsa decemlineata Say) in 1983 , its control and prognosis of appearances in 1984, pp. 229242. In, Materials of XXIV Scientific Sessions of the Institute of Plant Protection.

Porretta, D., D. Canestrelli, R. Bellini, G. Celli, and S. Urbanelli. 2007. Improving insect pest management through population genetic data: a case study of the mosquito Ochlerotatus caspius (Pallas). Journal of Applied Ecology 44: 682-691.

Ratnasingham, S., and P. D. N. Hebert. 2007. BOLD: The Barcode of Life Data System (www.barcodinglife.org). Mol Ecol Notes 7: 355364.

Say, T. 1824. Descriptions of coleopterous insects collected in the late expedition to the Rocky Mts., performed by order of Mr. Calhoun, Secretary of War, under the command of Major Long. Journal of the Academy of Natural Sciences of Philadelphia 3: 298-331.
Tsutsui, N.D., A.V. Suarez, D.A. Holway, and T.J. Case. 2000. Reduced genetic variation and the success of an invasive species. Proceedings of the National Academy of Sciences of the United States of America 97: 5948-5953.

Walczak, F., A. Bandyk, M. Jakubowska, K. Roik, A. Tratwal, B. Wielkopolan, and J. Złotkowski. 2013. Phytosanitary condition of crops in Poland in 2012 and expected occurrence of pests in 2013. Poznań: IOR-PIB.

Węgorek, W. 1949. Biological observations on the Colorado potato beetle (Leptinotarsa decemlineata Say) in 1948 in Irene near Demblin. Polish Journal of Entomology 19: 208-231.

Weegorek, W. 1959. Colorado potato beetle (Leptinotarsa decemlineata Say). Scientific dissertations. Institute of Plant Protection . vol. 1 (2), 164 ss.

Zehnder, G.W., L.L. Sandall, A.M. Tisler, and T.O. Powers. 1992. Mitochondrial DNA diversity among 17 geographic populations of Leptinotarsa decemlineata (Coleoptera: Chrysomelidae). Annals of the Entomological Society of America 85: 234-240.

Zhang, J.J., J. Yang, Y.C. Li, N. Liu, and R.Z. Zhang. 2013. Genetic relationships of introduced Colorado potato beetle Leptinotarsa decemlineata populations in Xinjiang, China. Insect Science 20: $643-654$ 